\title{
O conforto que veio do traçado das crianças de terreiro
}

\section{The comfort that came from the layout of the terreiro children}

\section{La comodidad que brinda la disposición de los niños del terreiro}

Janaína Corrêa $^{1}$

\section{RESUMO}

A pandemia da COVID-19 que assolou nosso planeta, trouxe consequências drásticas para as famílias e uma delas foi o isolamento social. Vários foram as estratégias ao redor do mundo de fazer com que esse afastamento não virasse patologia, músicas na janela, "chuva" de lives, recebidos e muitas vídeo-chamadas. O presente trabalho tem por objetivo dialogar com os desenhos que as crianças do terreiro Omi Larè Iya ${ }^{2}$ Sagbá fizeram nesse período. A ideia era que as crianças fizessem desenhos dos seus respectivos orixás e compartilhassem no grupo de Watsap do asé, seria um afago para as pessoas do terreiro ver imagens produzidas pelas crianças com mensagens de que ficaria tudo bem. Segundo Beniste o "orixá são divindades representadas pela energia da natureza, forças que alimentam a vida a terra, agindo de forma intermediária entre Deus e as pessoas". Logo o acolhimento vai vir das matas, das águas doces e salgadas, da terra, da chuva, dos raios e trovões. Para Sarmento "o desenho infantil comunica, as imagens são evocativas e referências de modo distinto e para além do que a linguagem verbal pode fazer”. Assim vai seguir este trabalho além do verbal.

Palavras-Chave: Crianças de Terreiro; Desenhos; Pandemia; Cotidianos.

\section{ABSTRACT}

TheCOVID-19 pandemic that devastated our planet had drastic consequences for families and one of them was social isolation. There were several strategies around the world to make this distance not turn into pathology, songs in the window, "rain" of lives, receptions and many video calls. The present work aims to dialogue with the drawings that the children of the Omi Larè Iya Sagbá terreiro made during this period. The idea was for the children to make drawings of their respective orixás and share them in the Watsap do asé group, it would be a caress for the people in the terreiro to see images produced by the children with messages that everything would be fine. According to Beniste, "orisha are divinities represented by the energy of nature, forces that feed the earth's life, acting as an intermediary between God and people". Soon, the welcome will come from the woods, fresh and salt water, earth, rain, lightning and thunder. For Sarmento "children's drawing communicates, images are evocative and references in a different way and beyond what verbal language can do". So go ahead with this work beyond

Submetido em: 23/06/2021 - Aceito em: 23/06/2021 - Publicado em: 12/07/2021

1 Mestranda em Educação pelo PROPED/UERJ, participante do grupo kekeré, professora na SEEDUC-RJ. E-mail: janinaviana@yahoo.com.br 2 Nome do terreiro onde foi feito o trabalho e quer dizer "Casa da força vital do herdeiro das águas de mãe Sagba" 


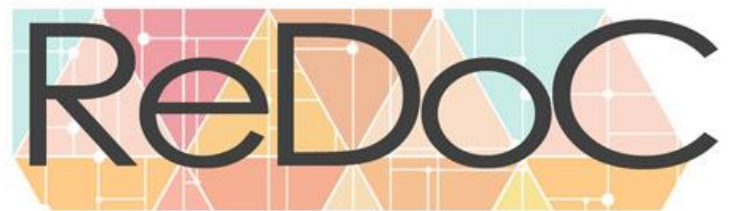

\section{Revista Docência e Cibercultura}

the verb.

KEYWORDS: Children of Terreiro; Graphics; Pandemic; Everyday.

\section{RESUMEN}

La pandemia de COVID-19 que devastó nuestro planeta tuvo consecuencias drásticas para las familias y una de ellas fue el aislamiento social. Hubo varias estrategias alrededor del mundo para que esta distancia no se convierta en patología, canciones en la ventana, "lluvia" de vidas, recepciones y muchas videollamadas. El presente trabajo pretende dialogar con los dibujos que los niños del terreiro Omi Larè Iya Sagbá realizaron durante este período. La idea era que los niños hicieran dibujos de sus respectivos orixás y los compartieran en el grupo Watsap do asé, sería una caricia para la gente del terreiro ver imágenes producidas por los niños con mensajes de que todo estaría bien. Según Beniste, "los orisha son divinidades representadas por la energía de la naturaleza, fuerzas que alimentan la vida de la tierra, actuando como intermediarios entre Dios y las personas". Pronto, la bienvenida vendrá del bosque, agua dulce y salada, tierra, lluvia, relámpagos y truenos. Para Sarmento "el dibujo infantil comunica, las imágenes son evocadoras y referentes de una forma diferente y más allá de lo que puede hacer el lenguaje verbal". Así que adelante con este trabajo más allá de lo verbal.

PALABRAS CLAVE: Hijos de Terreiro; Gráficos; Pandemia; Cada día.

\section{"Quando eu tinha 15 anos sabia desenhar como Rafael, mas precisei uma vida inteira para aprender desenhar como as crianças" Pablo Picasso}

Era o segundo mês que estávamos vivendo uma quarentena em função da pandemia provocada pela Covid-19. Foi transmitida através dos meios de comunicação, uma campanha na Itália em que as crianças eram incentivadas a colocar um arco-íris na janela. A ideia era dar esperança para as crianças que não podiam sair de casa naquele momento. Pensei que algo parecido poderia ser feito com as crianças do terreiro em que faço parte, o Ilê Axé Omí Larè İyá Ságbá. Terreiro $^{3}$ de candomblé ${ }^{4}$ situado em Duque de Caxias, na Baixada Fluminense, comandado pelo Babá ${ }^{5}$ Daniel de Iemanjá6.

A proposta foi pedir que as crianças que desenhassem seus orixás com a mensagem "vai ficar tudo bem". O resultado seria compartilhado no grupo fechado do WatsApp, na esperança de proporcionar um alento, principalmente, para os profissionais de saúde do terreiro que estão atuando no combate da pandemia. Falei então com o Ojuamadê, a pessoa no terreiro cujo o

\footnotetext{
${ }^{3}$ Espaço físico onde acontecem os cultos de matriz africana.

${ }^{4}$ Religião de matriz africana nascida na diáspora brasileira, símbolo de resistência e preservação da cultura africana.

${ }^{5}$ Pai de santo, líder do terreiro, variação de Babalorixá.

${ }^{6}$ Divindade das águas salgadas
} 
cargo tem por responsabilidade, zelar espiritualmente pelas crianças do barracão ${ }^{7}$. A resposta revelou uma comoção por todos e a ideia foi espalhada entre todos os filhos e filhas de santo da casa. A exposição das crianças é sempre uma preocupação e por esse motivo, foi escolhido, inicialmente os grupos fechados para publicação ${ }^{8}$.

As crianças sempre estavam presentes no cotidiano do terreiro. Na pandemia, o terreiro passou a ser a casa delas, foi de lá que elas fizeram seus pedidos para que ficasse tudo bem, foi de casa delas que mandaram suas mensagens, seus desenhos, "arriaram"9 seus saberes diaspóricos sobre os orixás. As roupas que vestiam, as ferramentas ${ }^{10}$ que cada um carrega em suas mãos. Dofona ${ }^{11}$ Ivy sabe que quando pede a Iansã está pedindo a força do vento que afaste a doença pra longe, Dofona Carolina ao conversar com Oxosse ${ }^{12}$ sabe que a flecha dele vai ser certeira na busca da cura da doença, Sophie tem certeza que Iansã tem a leveza da borboleta, mas que seu raio pode ser contundente acertando o negativo que traz a doença que nos atinge. Para nós, o terreiro é a casa, o terreiro é a rede social, o terreiro são as crianças.

Para Borges e Silva (2019) "O olhar ocidental dificulta a tentativa de compreensão, levando a ver as religiosidades de matriz africana como macabra e primitiva”. O terreiro é um espaço onde fortalecemos nossas lutas e a COVID-19 era mais uma, os desenhos foram uma forma de afago, principalmente com os profissionais da saúde que temos em nosso terreiro e que estavam frente, inclusive, o Babalorisá Daniel de Iemanjá que é médico. A ideia é que assim como "nossos saberes ancestrais superam a dor e o sofrimento da travessia e do mar", BORGES E SILVA (2019) esses desenhos nos ajudasse a atravessar também a angústia de estarmos distantes uns dos outros, através dos traços das nossas crianças.

Seguindo os rastros de Cristiano Sant'Anna denominaremos também esse trabalho de "fotoartigo" (SANT’ANNA, 2019). Mais de 30 desenhos foram produzidos pelas crianças do terreiro com idade de 1 a 14 anos. Para esse "fotoartigo" selecionamos somente alguns desenhos para dialogar com o nosso trabalho.

Para Sarmento (2011,p.20), o desenho infantil insere-se entre as mais importantes formas de expressão simbólica das crianças.

Desde logo, porque o desenho precede a comunicação escrita (na verdade, precede mesmo a comunicação oral, dado que os bebés rabiscam antes ainda

\footnotetext{
${ }^{7}$ Uma outra maneira de dizer terreiro, espaço em que acontece os cultos.

${ }^{8}$ As fotos foram publicadas no grupo de watsap e grupo fechado do terreiro no facebook com autorização das crianças e dos responsáveis.

${ }^{9}$ No candomblé quando colocamos uma oferenda para uma entidade ou orixá chamamos esse ato de "arriar"

${ }^{10}$ São objetos que os orixás costumam carregar, espécie de armas para o povo yorubá.

${ }^{11}$ Primeira pessoa do grupo que se inicia junto

${ }^{12}$ Divindade masculina das matas, caçador.
} 
de articularem as primeiras palavras). Depois, porque o desenho infantil, não sendo apenas a representação de uma realidade que lhe é exterior, transporta, no gesto que o inscreve, formas infantis de apreensão do mundo - no duplo sentido que esta expressão permite de "incorporação" pela criança da realidade externa e de "aprisionamento" do mundo pelo acto de inscrição - articuladas com as diferentes fases etárias e a diversidade cultural. Nesse sentido o desenho infantil comunica, e fá-lo dado que as imagens são evocativas e referenciais de modo distinto e para além do que a linguagem verbal pode fazer.

Sarmento diz também que os estudos sobre desenhos das crianças seguem a linha da Psicologia do Desenvolvimento como expressão da subjetividade em formação. Então em cada fase a criança tem um traço que está se encaminhando para o traço perfeito que é o traço da idade adulta, todavia o autor nos mostra que esse estudo deve ir além das marcas do desenvolvimento.

A abian ${ }^{13}$ Alice de 5 anos estava no Pré-1 em atividade remota e ainda não sabia escrever, teve ajuda da sua mãe Nathalia também abian do terreiro. Para as crianças que ainda não tem seu orixá definido ${ }^{14}$ foi pedido que fizessem um desenho de Iemanjá ou um desenho de Oxalá ${ }^{15}$, pois estes orixás são considerados pais de todos os outros orixás. Alice por ser ainda abian e não ter conhecimento dos rituais, sua mãe mostrou uma foto de Iemanjá da internet e Alice foi fazendo o seu traçado. Ela é uma menina muito espoleta, fez uma pose e com muito orgulho exibiu o seu desenho.

\footnotetext{
${ }^{13}$ Aquele que ainda não foi iniciado

${ }^{14}$ Os orixá de cada um é revelado através do oráculo do jogo de búzios, alguém que ainda não foi iniciado a maioria das vezes ainda não sabe qual é o seu orixá.

${ }^{15}$ Orixá mais velho do panteão Yourubá.
} 


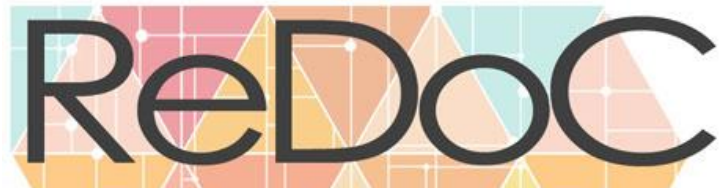

Revista Docência e Cibercultura

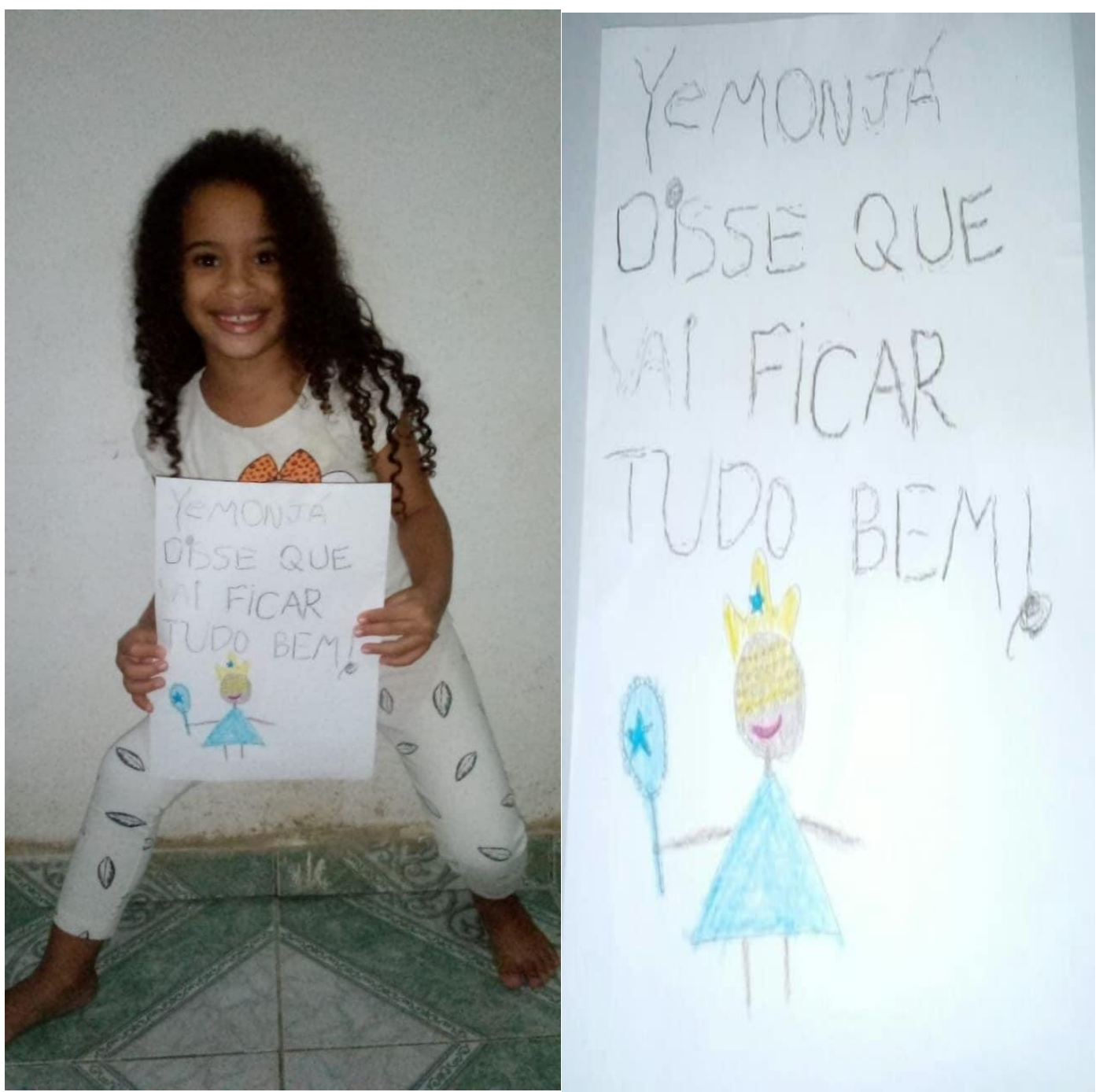

Figura 1. Abian Alice -6 Anos

Foto: Abian Natália

Dofona ${ }^{16}$ Ivy de lansã ${ }^{17}$ na época em que foi feito os desenhos ainda era abian, estava com 13 anos, cursando o $7^{\circ}$ ano do Ensino Fundamental, cumprindo remotamente. Ivy relatou não levar muito jeito para desenhar e pediu ideia para sua mãe, Egbomi Sara. Ivy escolheu ao rosa porque é a cor que seu orixá usa, ela foi a única criança que optou em fazer o rosto quando questionada o porquê de ter optado pelo rosto diz que não sabia desenhar o que

\footnotetext{
${ }^{16}$ Nome que se recebe o primeiro na posição quando um grupo de pessoas são iniciadas juntas.

${ }^{17}$ Deusa dos ventos e raios para a cultura Yourubá.
} 


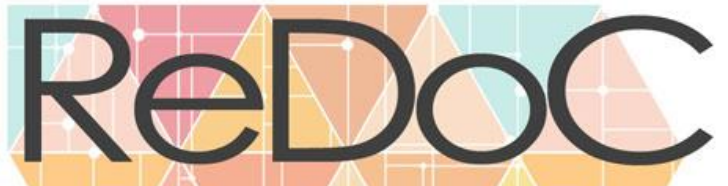

Revista Docência e Cibercultura

estava imaginando, mas eu ouso dizer que ficaria mais claro mostrar o que lansã é pra ela "Uma mulher guerreira, trabalhadora, forte e que passou por tantas coisas mais nunca desistiu, é amor de minha vida".

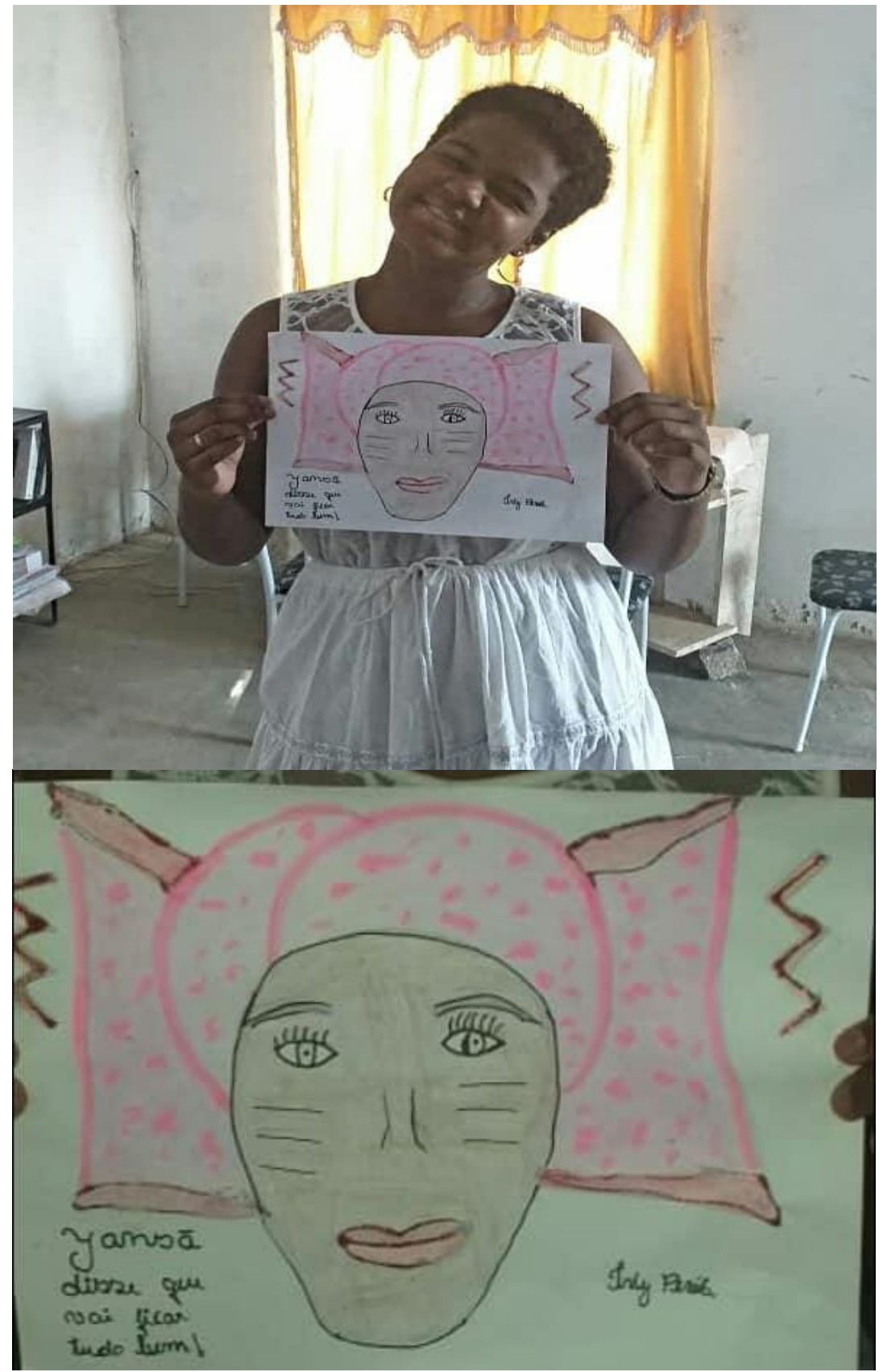

Figura 2. Dofona Ivy de Iansã Foto: Egbomy Sara de Oxoguian 
Dofona Ana Carolina de Oxosse, filha de Egbomi Márcia de lemanjá, havia acabado de ser iniciada quando começou a Pandemia, tinha 14 anos, cursando o $9^{\circ}$ ano do Ensino Fundamental em Ensino Remoto. Dofona Carol, como a chamamos, carinhosamente, relata que não tem muito hábito de desenhar, mas caprichou no desenho porque pra ela Oxosse é " minha vida, meu porto seguro e minha âncora", ela também fala do ponto positivo da Pandemia que foi a proximidade com a sua família, "eu acho que nós tivemos oportunidade de conhecer uns aos outros."
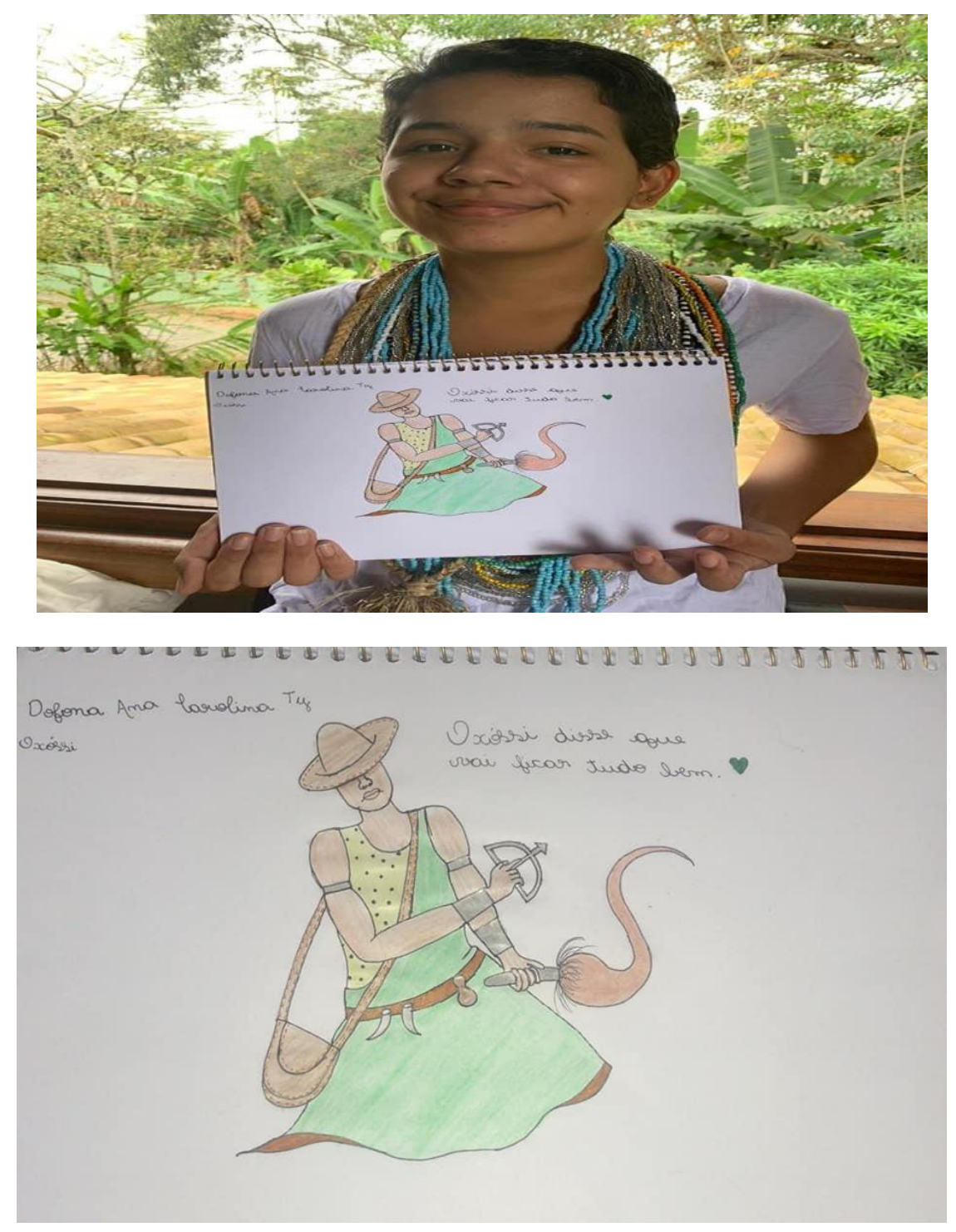

Figura 3. Dofona Carol de Oxosse Foto: Egbomi Márcia de lemanjá 


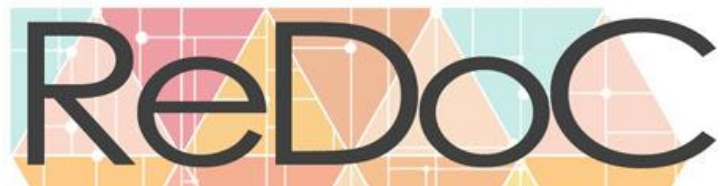

Revista Docência e Cibercultura

Dofona Sophie de Iansã é filha de Dofona Gabriela do mesmo terreiro, tinha 6 anos, estava no $1^{\circ}$ ano do Ensino Fundamental, ano de alfabetização, fez seu desenho sem ajuda da mãe, a orientação foi apenas sobre a frase. Usou as cores de Iansã e um detalhe muito rico do seu desenho foram as borboletas. Laba-laba ${ }^{18}$ é uma das representações de Iansã.
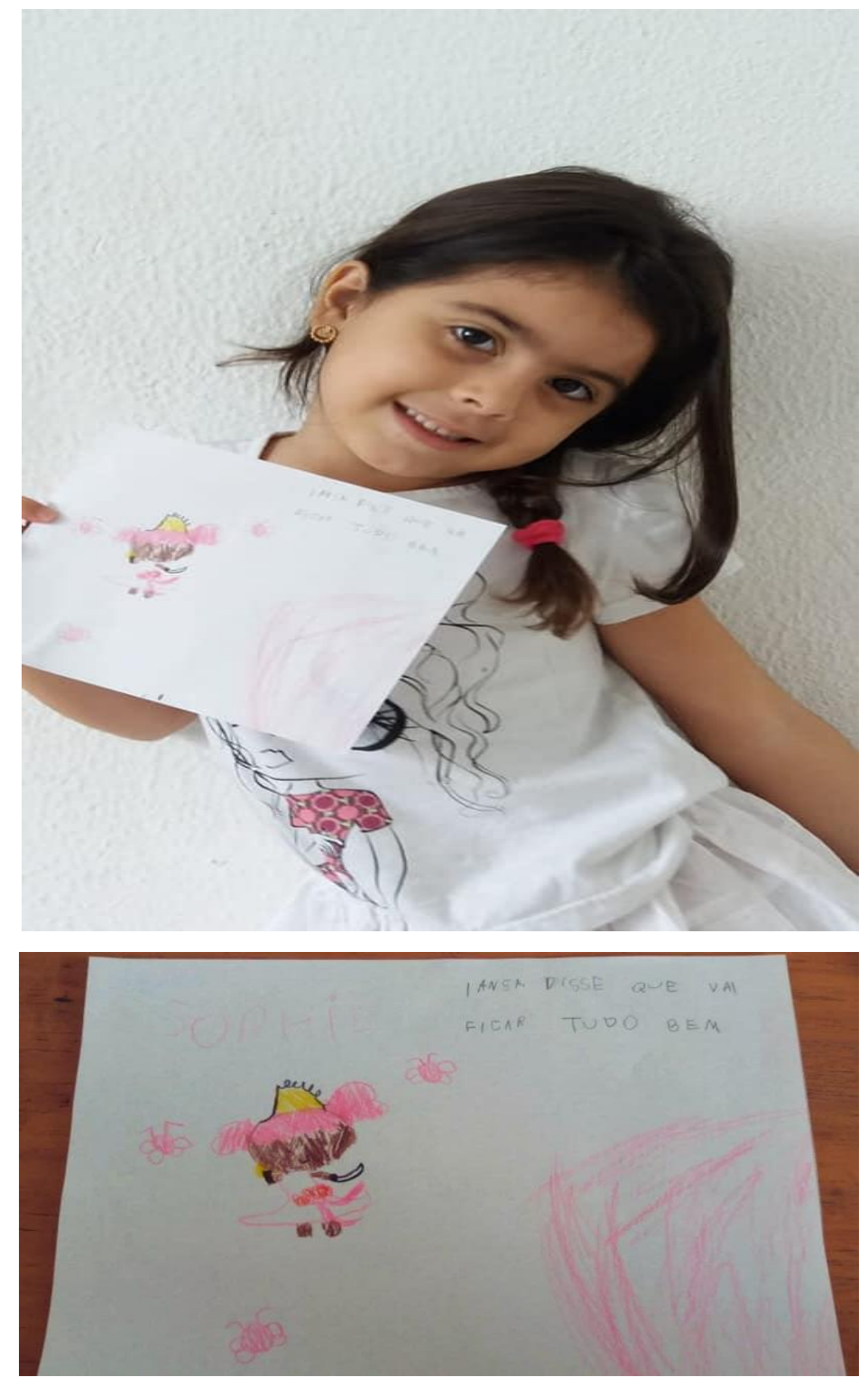

Figura 4. Dofona Sophie de lansã Foto: Dofona Gabriela de Oxum

18 Borboleta em Yourubá 
Abian Vicente também não sabia ainda seu orixá, como eu já havia dito anteriormente as crianças que ainda não sabia seu orixá foram orientadas a desenhar Iemanjá ou então Oxalá, mas o abian Vicente apesar de não saber seu orixá é fascinado por Ogum e o desenhou. Vicente desenhou Iemanjá também, traçou como se Iemanjá fosse uma pequena sereia . Vicente tinha 6 anos e estava estudando apenas remoto, segundo sua mãe a Pandemia não o abalou muito, pois ele teve a oportunidade de ficar mais tempo com o seu pai.
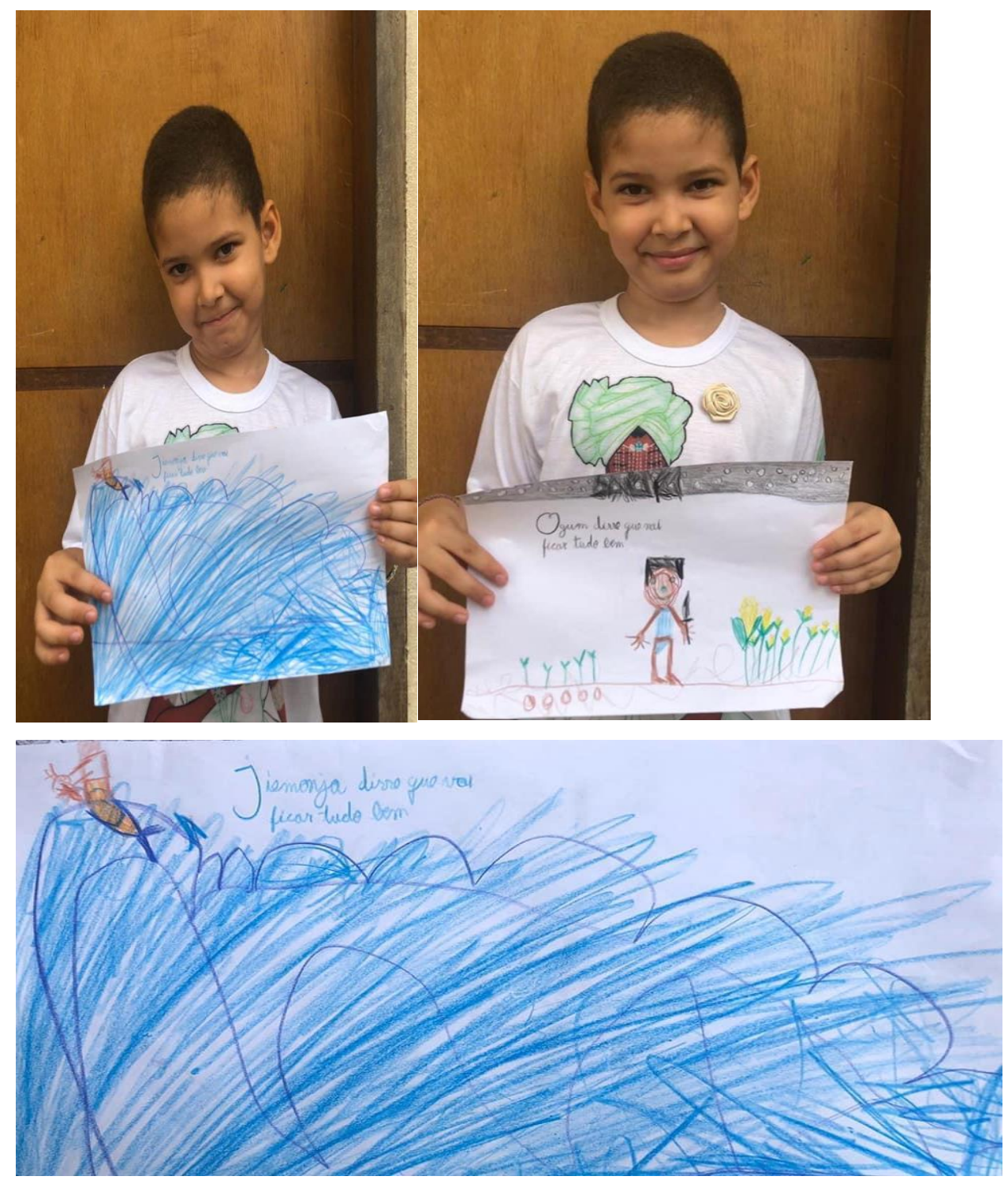

Figura 5. Abian Vicente

Foto: Dofonitinho Jose de Oxalá 


\section{REFERÊNCIAS}

BENISTE, José. Dicionário Yorubá - Português. Betrand Brasil. $2^{\circ}$ edição. Rio de Janeiro, 2014

BORGES, Luzineide Maria E SILVA, Marta Ferreira (2019) Redes Educativas no Contexto da Cibercltura: Crianças de/no/ de/no terreiro traçando os seus saberes. Argumentos Pró-Educação, Pouso Alegre, Dossiê - Infâncias e crianças indígenas, quilombolas e de outros povos tradicionais: (re) existências e agenciamentos, 2020 ISSN: 2448-2803

http://dx.doi.org/10.24280/ape.v5: e63

SANT'ANNA, Cristiano (2019). A força ancestral feminina no mar de Iemanjá - um fotoartigo. Redoc Rio de Janeiro v. 3 n.3 p. 271 Set/Dez 2019

SARMENTO, Manuel Jacinto (2011). "Conhecer a infância: os desenhos das crianças como produções simbólicas", in A.J. Martins Filho \& P.D. Prado (orgs), Das Pesquisas com Crianças à Complexidade da Infância. Campinas, Autores Associados; pp.: 27-60. ISBN 97885-7496-201-6.

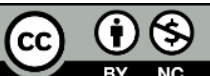

Este é um artigo de acesso aberto distribuído sob os termos da Licença Creative Commons Atribuição Não Comercial-Compartilha Igual (CC BY-NC- 4.0), que permite uso, distribuição e reprodução para fins não comerciais, com a citação dos autores e da fonte original e sob a mesma licença. 